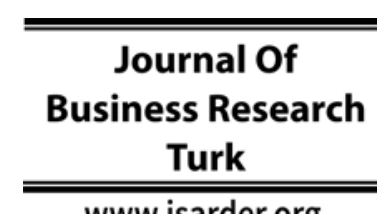

www.isarder.org

\title{
Do Stock Prices React to Illegal Corporate Behaviors? The Turkish Case
}

\author{
Sefa TAKMAZ \\ Adnan Menderes University \\ Faculty of Economics and Administrative \\ Sciences, Department of International \\ Trade and Finance \\ Nazilli, Aydin, Turkey \\ orcid.org/0000-0003-1428-3796 \\ sefatakmaz@gmail.com
}

\author{
Emel Mihriban KELEŞ
}

Adnan Menderes University

Faculty of Economics and Administrative

Sciences, Department of Labour

Economics

Nazilli, Aydın, Turkey

orcid.org/0000-0002-5435-8265

emelkeless@icloud.com

\begin{abstract}
This paper investigates the influence of illegal corporate behaviour on the stock performance of Turkish listed firms. The sample covers all firms traded in Borsa Istanbul between the years 2007 and 2016. The sample of firms violating laws are collected from Capital Market Board of Turkey weekly bulletins. In total 101 cases of violation are detected for 72 firms. Relevant stock price and benchmark index price data is collected from Thomson Reuters DataStream. For the analysis, event study methodology is used. Event methodology is suitable to examine the impact of an event on the stock price of a firm.

Consistent with prior studies in this field originated from US markets and proliferated in other developed markets and emerging markets, the results of this study demonstrate the evidence of a negative effect of the announcement on the stock price of firms that conducted an illegal behaviour. Specifically, we find that risk-adjusted average abnormal returns of firms violating laws are significantly negative on the event day. In addition, for the 11-day event window cumulative average abnormal returns are significantly negative. Two other longer event windows, 21-day and 41-day, display similar results. This confirms that investors in Turkey penalize illegal corporate actions like their counterparts in other countries.
\end{abstract}

Keywords: Violations, Event Study, Financial Performance

\section{Introduction}

In the last two decades, ethical investment or socially responsible investment became a popular topic in the business ethics literature. Ethical investment can be defined as the concern of personal values, social considerations and economic factors while making an investment decision (Michelson et al., 2004). There has been an ongoing debate in the literature for the following questions; "Does ethical consideration on investment decisions pay?" or in other words "Does unethical behaviors have an impact on the overall performance of the firm?" (Donker et al., 2008). Some studies indicate that there is not a clear connection between ethical conducts (i.e. social 
responsibility) and financial performance (Aupperle et al., 1985; Hawley, 1991). On contrary, other empirical studies empirically assert that ethical behaviors of the firms are awarded, and unethical behaviors are punished (Arnold and Engelen, 2007; Gunthorpe, 1997). According to the results of these studies, firms should consider ethical issues on reaching their goal of maximization of the market value or shareholder wealth.

Stock prices of publicly traded firms represent the market value of firms. So, stock prices serve as a scorecard for the managerial performance that measures the success and failure of managers (Davidson et al., 1994). Firms with an inferior performance measured by stock prices are open to corporate takeovers. If a firm is not managed properly it can be taken over and inefficient managers in charge can be replaced by new managers (Caiazza and Pozzolo, 2016). Likewise, declaration of an illegal or unethical behavior can damage the reputation of the firm and the managers. If stock prices react negatively to illegal behavior, it may discipline the managers for their actions. Otherwise, managers can behave autonomously without giving importance to the ethical issues. In this context, studying the impact of unethical or illegal behavior on the stock prices is meaningful.

The objective of this paper to analyze the effects of illegal corporate behavior on the financial performance of firms that are traded in Borsa Istanbul (BIST). As a sample, we examine all the traded firms in BIST for the period, 2007-2016. During this period, firms traded in BIST have committed a total of 101 illegal actions. We compiled illegal actions from the weekly bulletins of Capital Markets Board of Turkey (CMBT). Every week CMBT releases a bulletin that includes the illegal actions taken by the listed firms in BIST. Those illegal behaviours are penalized by CMBT. By using stock market reaction to violations, we managed to show that illegal behaviour negatively affects the financial performance of firms that committed violations. Results are statistically significant.

Studies in ethical behavior on financial performance generally focus on developed countries (Zeidan, 2013). As an emerging market, to our knowledge, Turkey has never been studied regarding the effects of illegal behavior on financial performance. So, by using event study methodology, main contribution of this study is to reveal evidence on the relationship between illegal business conducts and financial performance in an emerging market, Turkey.

The rest of this paper is organized as follows. Section II gives brief review of related literature. Then, the data and methodology are discussed, the stock exchange and the regulatory body of capital markets in Turkey are presented in section III. Empirical results are shown in section IV and the section V concludes.

\section{Literature Review}

The relationship between social responsibility and financial performance has been widely studied in the literature. There are mainly two types of studies regarding the span of the impact; short-run effects of ethical or unethical conducts on the financial performance and long-run relationship between social responsibility and financial performance of firms.

In the first type, generally event study methodology is used to evaluate the effects of unethical behavior. There is not a consensus in these studies. Results of the study by 
Wright and Ferris (1997) state a negative relationship, Poskinoff (1997) reveal a positive relationship; whereas Teoh et al. (1999) show that there is no relationship between social responsibility and financial performance.

The other type of studies examines long run relationship. Again, there is no lucid result. This type of studies generally uses accounting and financial measures relating profitability. Arlow and Gannon (1982) find that there is an insignificant relationship between social responsiveness and economic performance. Nevertheless, in their study McGuire et al. (1988) find that corporate social responsibility and financial performance show a strong correlation. In addition, after controlling for the age of assets, findings of Cochran and Wood (1984) also support the direct effect of ethical conducts on financial performance. The study of Waddock and Graves (1997) also states a positive relationship between social responsibility and financial performance using the return on asset (ROA) criteria.

The measurement type of financial performance is also an issue to be considered. In the literature, there are studies using accounting measures and there are studies using market measures (i.e. stock prices) as a proxy for financial performance. The two types of proxies have their own perspectives. Accounting measures can be subject to managerial manipulations and different accounting procedures can yield different results. On the other hand, market measures based on the choices of all investors in the market, reflect the overall expectation of the future financial performance of a firm. According to efficient market hypothesis, the price of a stock reflects all the available information affecting the performance of the firm. Thus, for instance, using the stock price as a market measure enables the researcher to evaluate the effect of information related to the unethical conduct of the firm.

The prevailing methodology to measure the short-term impact of unethical conduct on the share price of the firm is the event study method. This method, based on the notion of the market efficiency, gauges the effect of announced information on the share price. Latest information is quickly absorbed in the prices of the share if the market is accepted to be semi-strong efficient (MacKinlay, 1997). Event studies generally use abnormal returns sourcing from the newly arrived information. Abnormal returns are calculated after adjusting the returns for the normal (average) returns, which is subtracting the expected from actual return. Taking the announcement day as the beginning day and cumulating the abnormal returns over several days, cumulative abnormal returns are calculated. If the cumulative abnormal returns are significant, then it can be concluded that event has a significant effect on the share price. Wright et. al. (1995) and Klassen and McLaughlin (1996) both use event study method to examine the effect of positive and negative announcements on the share price. They find a negative reaction to negative announcements therefore incurring a cost to shareholder. Basdas and Oran (2014) document the event studies conducted in Turkey. Their findings reveal that no event study exists analyzing the effect of illegal actions on the financial performance of Turkish firms. Other econometric models used to analyze the relationship between social responsibility and financial performance can be found in the study of Curran (2003) where past studies are reviewed. 


\subsection{Empirical Studies on Developed Markets}

\subsubsection{Studies on US market}

Most research on the effect of corporate illegal behavior on financial performance is empirically studied for US market. In one of the early studies, Strachan et al. (1983) examine the influence of alleged corporate crime on the stock prices. They use 84 firms that are accused of illegal act as a sample from US market. As the methodology, meanadjusted abnormal returns are used to measure the effect of the illegal behavior announcement. To find the mean return for a firm, a period between 275 days and 26 days prior to the event day is chosen. The event window they choose to calculate the abnormal return is between 25 days prior to the event and 10 days after the event. Results of the empirical analysis show that announcements of illegal acts of firms negatively affect the stock returns. The day before the announcement and the announcement day have the largest negative returns.

In a meta-analysis paper, Frooman (1997) finds that socially irresponsible and illegal corporate behaviour significantly and substantially has a negative effect on the wealth of shareholders by examining 27 event studies. He concludes that firms behaving socially responsible and obeying the laws is a wise behavior for firms. On the other hand, Marcus (1989) test whether abnormal returns can prevent illegal behavior of firms by using a sample of automobile industry. After the analysis, he concludes that stock market reaction has no power to lessen suspicious corporate behaviors. In addition to these studies, Baucus and Near (1991) claim that certain internal and external factors of firms have a relationship with illegal firm acts. They use Fortune 500 companies from US to test the relationship. Results of their study conclude that, there is positive link between firm size and illegal acts. Also, if a firm committed an illegal action before, it is more likely that it will happen again. They claim that this is a result of insufficient punishments. Alexander (1999) focus on the reputational penalty when a firm commits an illegal act. She uses the illegal actions of listed US firms between the years 1984 and 1990 as a sample. The result the study shows that firms, which pay reputational penalties, lose much more in shareholder wealth if the illegal action directly affects the related parties such as customers rather than third parties.

In another study on the influence of illegal corporate behavior on financial performance in US market is the study of Baucus and Baucus (1997). By using a sample period of 1974-1983, they examine the effect of illegality on long term financial performance of Fortune 300 firms. They find that financial performance is negatively affected from corporate illegal acts.

Davidson et al. (1994) study stock market reactions of illegal corporate behavior of firms listed in New York and American Stock Exchanges. Their study show that stock market reacts negatively to certain types of corporate crimes. In other words, the type of the crime determines the effect of stock market.

Allouche and Laroche (2005b) is another comprehensive meta-analytical study on the relationship between corporate financial performance and financial performance. The study examines 82 studies in total. 75 of these studies are US studies. Majority of the studies find that there is positive association between corporate social and financial performance. A limited number of studies show negative relationship. 
Murphy et al. (2009) examine the association between corporate misconducts and financial measures of US firms. The financial measures they use are earnings and risk. By analyzing corporate illegalities appeared on The Wall Street Journal Index for the period of 1982 and 1996, they find that misconducts decrease the earnings and increase the risk of firms. In a recent and comprehensive study, Haslem et al. (2017) also investigate the influence of corporate misconducts on the market value of US firms with a new sample of 83,260 lawsuits. They use event study methodology. To calculate the average and cumulative abnormal returns, they use a market model estimated over 131 days and 11 days prior to the event. Returns are calculated for three event windows; -10 and, -1 and 1, -10 and 10 . Results of the study clearly show that announcement of corporate illegalities negatively affects stock returns of firms.

\subsubsection{Studies on other Developed Markets}

Moore (2001) and Moore and Robson (2002) examine the social and financial performance of UK firms. These two studies analyse UK firms in supermarket industry. They use one industry as a sample but several measures of social and financial performance. The findings reveal that there is a positive linkage between prior-period financial performance and following-period social performance. Ogden and Watson (1999) also find that behaving in favor of stakeholders positively affects the shareholder wealth by analyzing UK firms operating in water supply industry. Armour et al. (2017) find that UK firms realize significant reputational and financial losses when they make a misconduct by using a sample of 341 events between the years 2001 and 2011 .

Makni et al. (2009) search for the causal relationship between financial performance and corporate social performance of firms in Canada. They use 179 listed firms as a sample for the years 2004 and 2005. By using Granger causality approach as methodology, they find that some aspects of corporate social performance are negatively associated with financial performance measures such as market return, return on equity and return on assets. Contrary to expectations, this result implies that socially responsible firms face with lower financial performance. That is being socially responsible do not pays. A recent study on Canadian firms by Cormier and Magnan (2017) investigates the effect of ethical violations on the financial performance. Ethical violations include actions such as violation of labor code, fraud, corruption and bribes among other violations. There are 182 firms in the sample for the year 2012. They find that ethical violations decrease the stock market valuation of firms.

Arnold and Engelen (2007) examine the market reaction of illegal corporate behaviour for firms two developed European countries, Belgium and Netherlands. For the sample period of 1994-2003, they find that share prices react negatively to announcements of illegal corporate actions.

Gillet et al. (2010) examine the effect of illegal events that damages reputation on the financial measures by using financial firms from developed European countries and US. They analyse the events occurred between 1990 and 2004. To the results, events have significant negative effect on the stock returns of firms. Particularly, negative abnormal returns are observed on the announcement day of the event. Fiordelisi et al. (2014) also carry out an event study on the influence of reputation damaging actions for a sample of European and US financial firms between the years 1994 and 2008. They find that announcement of actions resulted in negative abnormal returns. Specifically, fraud as an event type makes the most damage on reputation of the firm. 
In another study regarding financial sector, Köster and Pelster (2017) investigate the effects of financial penalties on the performance of banks from a large sample of countries namely, Australia, Canada, Israel, Western European Countries and United States. A total of 68 banks are examined with 671 financial penalties. Results indicate that financial penalties have no influence on after tax profitability of banks. In addition, they find that announcement of financial penalties leads to positive abnormal returns for banks in the sample. This can be explained as the banks' gain from illegal behaviors exceed the penalties given.

\subsection{Empirical Studies on Emerging Markets}

Empirical studies on emerging markets are not extensive as on developed countries. Mishra and Suar (2010) examine the influence of corporate social responsibility on firm performance for Indian firms. They find that firms listed in a stock exchange behave more responsible than unlisted firms. When they control for stock-listing, firm size and ownership, the results of the study reveal that social responsibility has a positive relationship with financial performance.

Song and Han (2017) analyze the stock market reaction to corporate crime in South Korean context. They examine the announcements of corporate crime in South Korea for the years between 2001 and 2010. In their analyses, they control for crime type, industry type, business group affiliation and corporate governance. In summary, they find that announcement of corporate crimes negatively affects the stock prices of Korean firms. In a more specific paper, Hovav et al. (2017) examine the effect of security related incidents on the abnormal stock returns of firms and the results of their study reveal a significant negative reaction to announcements of the events after the year 2007 for their sample.

In their study, Aggarwal et al. (2015) investigate stock market response to the announcement of fraudulent activities of firms in an important emerging market, China. The sample period for analysis is the years between 2001 and 2011. All firms listed in Chinese stock exchange are examined and a total of 750 fraud acts are determined. Empirical results of this study show that market reacts negatively to the announcement of fraudulent actions. The effect of negativity lasts for few weeks specifically for serious fraud cases. In another study, Wang and Li (2016) show that investors value corporate social responsibility by using a sample of listed non-financial firms from China for the years between 2007 and 2012.

\section{Data and Methodology}

For the empirical analysis, daily closing prices of publicly traded firms' stocks that alleged in illegal behavior are tested by using event study methodology for the period between 2007 and 2016. The data consists of a sample of all firms publicly traded in BIST and legally controlled by Capital Markets Board of Turkey. Below brief presentations of both entities are given, followed by details in data, tested hypothesis and methodology.

\subsection{Borsa Istanbul}

Because of a considerable improvement in the Turkish capital markets in 1980s, Borsa Istanbul ${ }^{1}$ (BIST) was formed in 1986 as the first organized stock exchange.

\footnotetext{
${ }^{1}$ www.imkb.gov.tr
} 
Tradable securities in BIST include equities, exchange traded funds, warrants, options, futures, certificates, debt instruments and lease certificates. BIST is one of the most important emerging stock market that is open for further improvement. It is a full member of "The World Federation of Exchanges" (WFE), "Federation of Euro-Asian Stock Exchanges" (FEAS), "Federation of European Securities Exchanges" (FESE), "International Islamic Financial Market" (IIFM) and "Association of Futures Markets" (AFM) among other international organizations. By the end of 2016, BIST has a market capitalization of about 158,000 million $\mathrm{USD}^{2}$. Compared with the end of 2008 global financial crisis, the market value of BIST has managed to grow about $45 \%$. The market capitalization relative to GDP is relatively low for the Turkish capital market with a 0,21 ratio. According to the statistics compiled from World Federation of Exchanges for 2016 , BIST is the $18^{\text {th }}$ biggest market in the world based on market capitalization ${ }^{3}$. Daily calculation of BIST indices first began in 1987. Stock market of BIST includes; national market, second national market, stars market, emerging companies market, control share premium market, watchlist market and pre-market trading platform market.

\subsection{Capital Markets Board of Turkey}

Capital Markets Board of Turkey $(\mathrm{CMB})^{4}$ is the regulatory and supervisory body in charge of the securities markets in Turkey. It is empowered by the Capital Markets Law (CML) enacted in 1981. Since its formation, the CMB has been making detailed regulations for organizing the markets and developing capital market instruments and institutions. Its main objectives are providing fair and orderly functioning markets and protecting the rights of investors. Besides, it has a wide range of responsibilities: to take the necessary measures for fostering the development of capital markets, and hence to contribute to the efficient allocation of financial resources in the country while ensuring investor protection.

\subsection{Data}

The data used in this study is obtained from Thomson Reuters and Capital Market Board of Turkey. The initial sample covers 101 illegal actions by the firms. But to prevent possible contamination of parameters sourcing from multiple violations happened in the estimation period, only one violation by a firm is included in the sample (Zeidan, 2013). After elimination of multiple violations, we are left with 72 events for all firms.

\subsection{Hypothesis}

Bad news regarding the company is expected to negatively affect the stock price of the company whereas good news is expected to positively affect stock prices. Being in the category of bad news, the announcement of an illegal act is expected to reduce the stock prices. The event study methodology examines if the average abnormal return on the event day is equal to zero as the null hypothesis versus it is not to zero as an alternative hypothesis. If the abnormal return is not equal to zero and if it is negative, then it can be concluded that announcement has a negative impact on the stock price.

Thus, the alternative hypothesis tested in this study is as follows:

\footnotetext{
${ }^{2} \mathrm{http}: / /$ www.borsaistanbul.com/en/data/data/consolidated-data

${ }^{3}$ www.spk.gov.tr

${ }^{4}$ www.spk.gov.tr
} 

returns.

$\mathrm{H}$ : Announced illegal actions taken by firms will lead to negative abnormal stock

\subsection{Methodology}

This study uses event study methodology to measure the effect of the announced illegal action of the firm. Event study methodology is a widely-used method in the literature. It takes its basis from the theory of efficient capital markets. In the semistrong form, the efficient capital market hypothesis states that stock prices fully reflect the all available information. Therefore, an announcement of any illegal act regarding a publicly traded corporation should be reflected immediately in the stock prices.

Consistent with the empirical model used in Gunthorpe (1997), the following steps are used to calculate the average abnormal returns to measure the price effect of an illegal act. The announcement of the illegal action is accepted as the event day and denoted as $t=0$ as the initial date. An event period of eleven days $-5 \leq t \leq 5$ is chosen. This event window is chosen because it not possible to know the exact timing of the information arrival to the market. Firstly, the logarithmic return of each stock on each day in the event period is computed as follows;

$$
R_{i, t}=\log \left(\frac{P_{i, t}}{P_{i, t-1}}\right)
$$

Then, the abnormal return for each stock on the two sub-periods is computed using a market-adjusted model:

$$
A R_{i, t}=R_{i, t}-E\left(R_{i, t}\right)
$$

Where $A R_{i, t}$ is the abnormal return on each stock $i$ for day $t$ in the event window $-5 \leq t \leq 5 ; ; R_{i, t}$ is the logarithmic return of each stock $i$ on day $t$ and $E\left(R_{i, t}\right)$ is the expected return on each stock $i$ for day $t$.

The expected return is calculated by the market model of:

$$
E\left(R_{i, t}\right)=\alpha_{i}+\beta_{i} * R_{m t}
$$

where $R_{m t}$ is the benchmark index. Return on BIST 100 index is used as the benchmark index. The estimation period of determining the expected return consists 120 trading days prior to event window. That is if $t=0$ (i.e. event day), then expected return is calculated by regressing the stock return over benchmark index between the days $t=-125$ and $t=-6$.

The actual event days for each stock in the sample can be different. Therefore, instead of using abnormal returns for each stock, average abnormal returns for the event window of eleven days are used. The average abnormal return $A A R_{t}$ is defined as;

$$
A A R_{t}=\sum_{i=1}^{N} A R_{i, t} / N
$$

where $N$ is the number of firms in the sample. To test the statistical significance of $A A R_{t}, \mathrm{Z}$ statistic is used and defined as:

$$
Z_{t}=\sqrt{N}\left(\frac{A A R_{t}}{\sigma_{t}}\right)
$$


where $\sigma_{t}$ is the standard deviation of abnormal returns on day $t$. As stated before if $A A R_{t}$ on the event day is significantly different than zero, it can be said that the announcement has an effect on the stock price. Nevertheless, in event studies it is difficult to define the exact day of the dissemination of the event. So, to capture the accumulated effect in the event window, the cumulative average abnormal returns, $C A A R_{t}$, are also examined. CAAR is defined as:

$$
\text { CAAR }_{t}=\sum_{t=-5}^{5} A A R_{t}
$$

We measured the statistical significance of $C A A R_{t}$ like the significance of $A A R_{t}$ with a Z statistic.

\subsection{Robustness}

For robustness, the calculations explained above are repeated for the event periods of 21 days $(-10 \leq t \leq 10)$ and 41 days $(-20 \leq t \leq 20)$. By this way, the effects of the events are checked for a longer period. In section 4.2. results of this additional calculations are compared with the results of 11 days period results.

\section{Empirical Results}

\subsection{Results}

The average daily abnormal returns from $t=-5$ to $t=5$ for the event study is reported in Table I. As shown, the average abnormal return for the announcement day, $\mathrm{t}=0$, is negative $\left(A A R_{0}=-0.75 \%\right)$ and significant at $10 \%$ level with a Z-statistic of -1.75. Day three and day four also show negative average abnormal returns with statistical significance. As a result, we can say that the announcement is reflected in the stock prices immediately and as expected it has a negative effect on the price of the stock. In addition, the cumulative average abnormal return is also negative $(C A A R=-2.85 \%)$ with a strong significance at $1 \%$ level $(Z$-statistic $=-2.70)$ as shown in Table II. Figure I graphically present the cumulative average abnormal returns for the event window.

Table I: Average Abnormal Returns

\begin{tabular}{|c|c|c|c|}
\hline Day & AARt & Z-Statistic & CAARt \\
\hline-5 & -0.0008 & -0.21 & -0.0008 \\
\hline-4 & -0.0033 & -0.91 & -0.0041 \\
\hline-3 & 0.0002 & 0.07 & -0.0039 \\
\hline-2 & 0.0004 & 0.12 & -0.0035 \\
\hline-1 & 0.0015 & 0.43 & -0.002 \\
\hline 0 & -0.0075 & $-1.75^{*}$ & -0.0095 \\
\hline 1 & -0.0047 & -1.34 & -0.0143 \\
\hline 2 & -0.0031 & -0.66 & -0.0174 \\
\hline 3 & -0.0064 & $-1.70^{*}$ & -0.0238 \\
\hline 4 & -0.0098 & $-3.14^{* * *}$ & -0.0336 \\
\hline 5 & 0.0051 & 1.05 & -0.0285 \\
\hline
\end{tabular}

*Denotes significance at the $10 \%$ confidence level

$* * *$ Denotes significance at the $1 \%$ level 
Table II: Cumulative Average Abnormal Returns

\begin{tabular}{|c|c|c|}
\hline Event window & CAAR & Z-Statistic \\
\hline$[-5,5]$ & $-2.85 \%$ & $-2.70 * * *$ \\
\hline
\end{tabular}

$* * *$ Denotes significance at the $1 \%$ level

Figure I: Cumulative Average Abnormal Returns

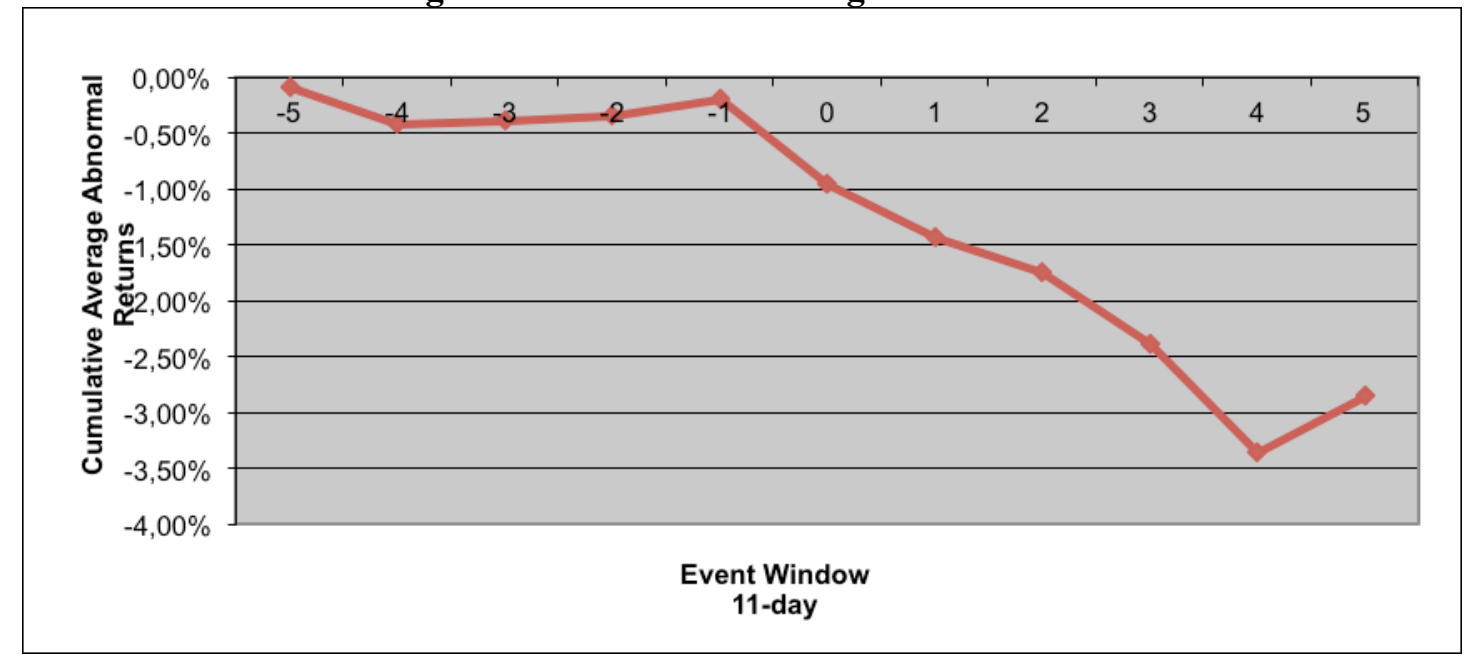

\subsection{Robust Results}

The results of 21-day and 41-day window robustness tests are presented in Table III.

Table III: Cumulative Average Abnormal Returns

\begin{tabular}{|c|c|c|}
\hline Event window & CAAR & Z-Statistic \\
\hline$[-10,10]$ & $-2.49 \%$ & -1.28 \\
\hline$[-20,20]$ & $-7.43 \%$ & $-3.02 * * *$ \\
\hline
\end{tabular}

$* * *$ Denotes significance at the $1 \%$ level

For both event windows, 21-day and 41-day, cumulative average abnormal returns are negative. The 21-day CAAR is $-2.49 \%$ and 41 -day CAAR is even higher with a value of $-7.43 \%$. 21-day CAAR is slightly not statistically significant at $10 \%$ level but we observe that 41 -day CAAR is highly significant at $1 \%$ level. Figure II and Figure III clearly show that longer period event window results support the result of 11-day event window result. Average abnormal returns are significantly negative for most of the days on the event day and following days. Thus, investors penalize the violation of regulations by reducing the share prices for an extended period after the event day.

Figure II: Cumulative Average Abnormal Returns

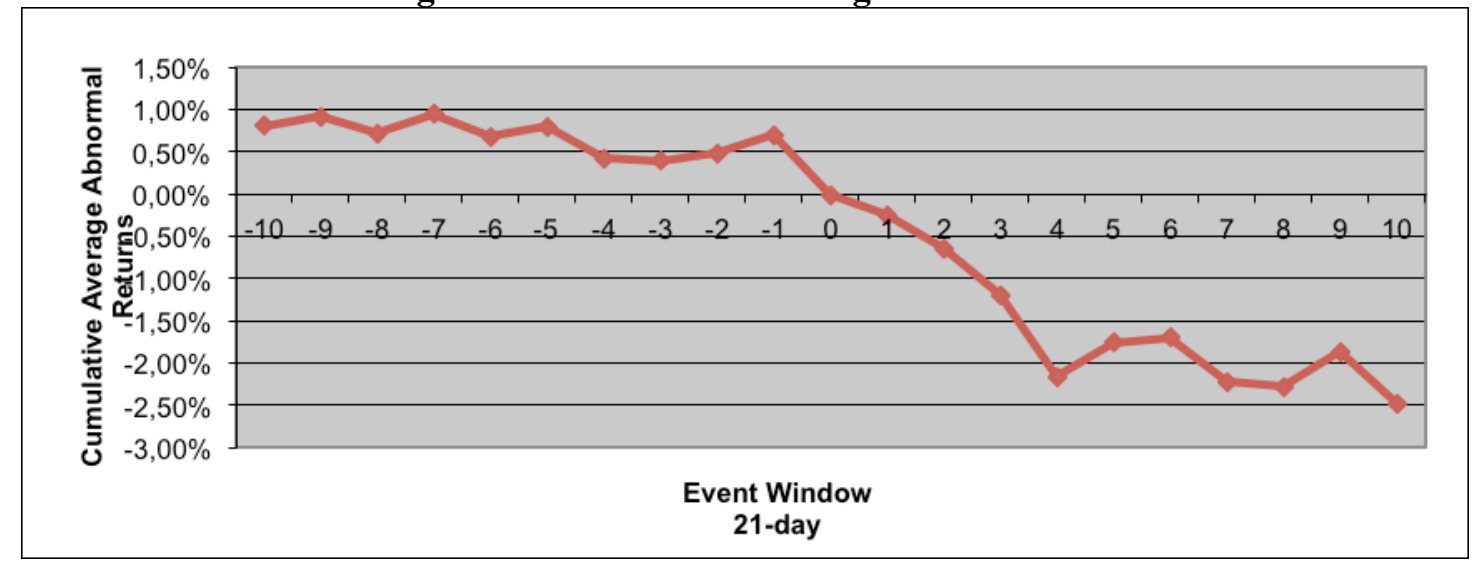


Figure III: Cumulative Average Abnormal Returns

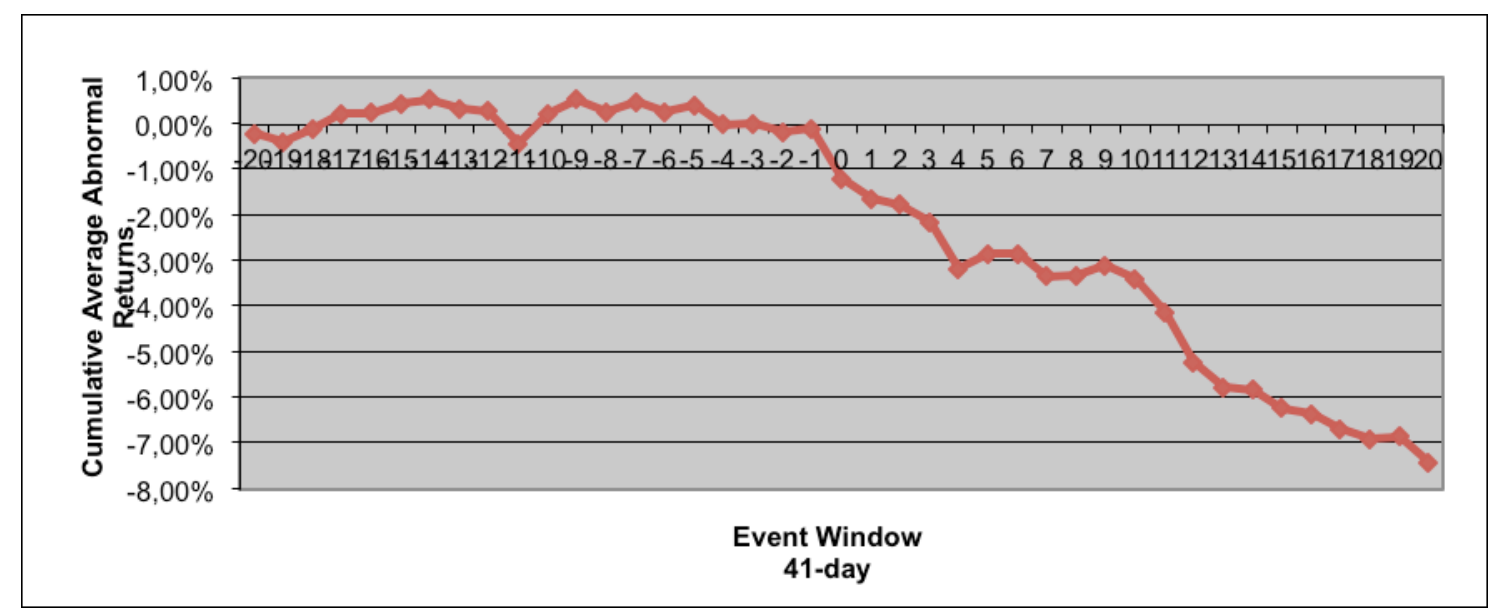

\section{Conclusion}

This study highlights the empirical evidence of the effect of unethical behaviors on the stock price in an emerging market. The empirical results show that the announcements of an illegal behavior by firms are penalized by the financial markets. The stock prices decline after the declaration of an unethical behavior not only on the event day but also on the following days. On the first day of the event an average of $0.75 \%$ (11-day event window) decline occurs in the stock prices. At the end of the event window this decline which can be called as a penalty for firms reaches to $2.85 \%$. The market clearly reacts negatively to the illegal behavior. In robustness tests for longer event windows results are similar. So, hypothesis of this study is supported.

In brief, the results of this study suggest that there is a financial incentive reflected in the stock prices for firms to behave ethically while making decisions. Future research might focus on the severity of the violation. The size of the firms, the riskiness of the firm and the industry of the firm might also be used as control variables to check the robustness of the results.

\section{References}

Aggarwal, R., Hu, M., Yang, J. (2015). Fraud, market reaction, and the role of institutional investors in Chinese listed firms. The Journal of Portfolio Management, 41(5), 92-109.

Alexander, C. R. (1999). On the nature of the reputational penalty for corporate crime: Evidence. The Journal of Law and Economics, 42(S1), 489-526.

Allouche, J., Laroche, P. (2005). A meta-analytical investigation of the relationship between corporate social and financial performance. Revue de gestion des ressources humaines, (57), 18.

Arlow, P., Gannon, M. J., (1982). Social responsiveness, corporate structure, and economic performance. Academy of Management Review, Vol. 7, No. 2, 235241.

Armour, J., Mayer, C., Polo, A. (2017). Regulatory sanctions and reputational damage in financial markets. Journal of Financial and Quantitative Analysis, 52(4), 14291448 . 
Arnold, M., Engelen, P. J., (2007). Do financial markets discipline firms for illegal corporate behaviour. Management \& marketing, Vol. 2, No. 4, 103-110.

Aupperle, K. E., Carroll, A. B., Hatfield, J. D., (1985). An empirical examination of the relationship between corporate social responsibility and profitability. Academy of management Journal, Vol. 28, No. 2, 446-463.

Basdas, U., Oran, A., (2014). Event studies in Turkey. Borsa Istanbul Review, Vol. 14, No. 3, 167-188.

Baucus, M. S., Near, J. P. (1991). Can illegal corporate behavior be predicted? An event history analysis. Academy of Management Journal, 34(1), 9-36.

Baucus, M. S., Baucus, D. A. (1997). Paying the piper: An empirical examination of longer- term financial consequences of illegal corporate behavior. Academy of Management Journal, 40(1), 129-151.

Caiazza, S., Pozzolo, A. F., (2016). The determinants of failed takeovers in the banking sector: Deal or country characteristics? Journal of Banking \& Finance, Vol. 72, 92-103.

Cochran, P. L., Wood, R. A., (1984). Corporate social responsibility and financial performance. Academy of management Journal, Vol. 27, No. 1, 42-56.

Cormier, D., Magnan, M. (2017). Does a firm's exposure to ethical failures matter to financial markets? A governance perspective. Journal of Management \& Governance, 21(2), 267-289.

Curran, M. M., (2003). A systematic review of the literature investigating the link between corporate social responsibility and financial performance. New Academy Review, Vol. 2, No. 3, 19-40.

Daboub, A. J., Rasheed, A. M., Priem, R. L., Gray, D. (1995). Top management team characteristics and corporate illegal activity. Academy of Management review, 20(1), 138-170.

Davidson, W. N., Worrell, D. L., Lee, C. I., (1994). Stock market reactions to announced corporate illegalities. Journal of Business Ethics, Vol. 13, No. 12, 979987.

Donker, H., Poff, D., Zahir, S., (2008). Corporate values, codes of ethics, and firm performance: A look at the Canadian context. Journal of Business Ethics, Vol. 82, No. 3, 527-537.

Fiordelisi, F., Soana, M. G., Schwizer, P. (2014). Reputational losses and operational risk in banking. The European Journal of Finance, 20(2), 105-124.

Frooman, J., (1997). Socially irresponsible and illegal behavior and shareholder wealth: A meta-analysis of event studies. Business \& Society, 36(3), 221-249.

Gillet, R., Hübner, G., Plunus, S. (2010). Operational risk and reputation in the financial industry. Journal of Banking \& Finance, 34(1), 224-235.

Gunthorpe, D. L., (1997). Business ethics: A quantitative analysis of the impact of unethical behavior by publicly traded corporations. Journal of Business Ethics, Vol. 16, No. 5, 537-543. 
Haslem, B., Hutton, I., Smith, A. H. (2017). How much do corporate defendants really lose? A new verdict on the reputation loss induced by corporate litigation. Financial Management.

Hawley, D. D., (1991). Business ethics and social responsibility in finance instruction: An abdication of responsibility. Journal of Business Ethics, Vol. 10, No. 9, 711721.

Hovav, A., Han, J., Kim, J. (2017). Market Reaction to Security Breach Announcements: Evidence from South Korea. ACM SIGMIS Database: the DATABASE for Advances in Information Systems, 48(1), 11-52.

Klassen, R. D., McLaughlin, C. P., (1996). The impact of environmental management on firm performance. Management science, Vol. 42, No. 8, 1199-1214.

Köster, H., Pelster, M. (2017). Financial penalties and bank performance. Journal of Banking \& Finance, 79, 57-73.

MacKinlay, A. C., (1997). Event studies in economics and finance. Journal of economic literature, Vol. 35, No. 1, 13-39.

Makni, R., Francoeur, C., Bellavance, F. (2009). Causality between corporate social performance and financial performance: Evidence from Canadian firms. Journal of Business Ethics, 89(3), 409-422.

Marcus, A. (1989). The deterrent to dubious corporate behavior: Profitability, probability and safety recalls. Strategic Management Journal, 10(3), 233-250.

McGuire, J. B., Sundgren, A., Schneeweis, T., (1988). Corporate social responsibility and firm financial performance. Academy of management Journal, Vol. 31, No. 4, 854-872.

Michelson, G., Wailes, N., Van Der Laan, S., Frost, G., (2004). Ethical investment processes and outcomes. Journal of Business Ethics, Vol. 52, No. 1, 1-10.

Mishra, S., Suar, D. (2010). Does corporate social responsibility influence firm performance of Indian companies?. Journal of Business ethics, 95(4), 571-601.

Moore, G. (2001). Corporate social and financial performance: An investigation in the UK supermarket industry. Journal of Business ethics, 34(3), 299-315.

Moore, G., Robson, A. (2002). The UK supermarket industry: an analysis of corporate social and financial performance. Business Ethics: A European Review, 11(1), 2539.

Murphy, D. L., Shrieves, R. E., Tibbs, S. L. (2009). Understanding the penalties associated with corporate misconduct: An empirical examination of earnings and risk. Journal of Financial and Quantitative Analysis, 44(1), 55-83.

Ogden, S., Watson, R. (1999). Corporate performance and stakeholder management: Balancing shareholder and customer interests in the UK privatized water industry. Academy of Management Journal, 42(5), 526-538.

Posnikoff, J. F., (1997). Disinvestment from South Africa: They did well by doing good. Contemporary Economic Policy, Vol. 15, No. 1, 76-86. 
Song, C., Han, S. H. (2017). Stock market reaction to corporate crime: Evidence from South Korea. Journal of Business Ethics, 143(2), 323-351.

Strachan, J. L., Smith, D. B., Beedles, W. L. (1983). The price reaction to (alleged) corporate crime. Financial Review, 18(2), 121-132.

Teoh, S. H., Welch, I., Wazzan, C. P., (1999). The effect of socially activist investment policies on the financial markets: Evidence from the South African boycott. The Journal of Business, Vol. 72, No. 1, 35-89.

Waddock, S. A., Graves, S. B., (1997). The corporate social performance-financial performance link. Strategic management journal, 303-319.

Wang, K. T., Li, D. (2016). Market reactions to the first-time disclosure of corporate social responsibility reports: Evidence from China. Journal of Business Ethics, 138(4), 661-682.

Wright, P., Ferris, S. P., Hiller, J. S., Kroll, M., (1995). Competitiveness through management of diversity: Effects on stock price valuation. Academy of Management Journal, Vol. 38, No. 1, 272-287.

Wright, P., Ferris, S. P., (1997). Agency conflict and corporate strategy: The effect of divestment on corporate value. Strategic Management Journal, 77-83.

Zeidan, M. J., (2013). Effects of illegal behavior on the financial performance of US banking institutions. Journal of Business Ethics, Vol. 112, No. 2, 313-324. 